\title{
SPOLEČNÉ ŘÍZENÍ O PŘESTUPCÍCH - VŽDY VE PROSPĚCH PACHATELE?
}

\author{
JAN MALAST
}

\begin{abstract}
Common Proceedings on Administrative Transgressions - Always in Favor of the Offender?

The paper deals with the issue of common proceedings on multiple administrative transgressions and the question of the applicability of this special type of proceedings in connection with the principle of absorption if their consequences would lead to a deterioration of the accused's legal situation, i.e. they would lead to a situation at expense of him.
\end{abstract}

Keywords: common proceedings; administrative transgression; principle of absorption

Klíčová slova: společné řízení; přestupek; absorpční zásada

DOI: $10.14712 / 23366478.2020 .17$

\section{1. ÚVOD}

Společné řízení vedené s pachatelem (obviněným) více přestupků ve spojení s absorpční zásadou uplatňovanou pak při ukládání správních trestů obecně řadíme mezi ty nástroje správního trestání, jejichž aplikace má vést nejen $\mathrm{k}$ rychlejšímu a efektivnějšímu rozhodování o souběžných přestupcích, ale také ke spravedlivějšímu a, řekněme, humánnějšímu ukládání správních trestů za tato vícečetná porušení právních povinností. Navzdory poměrně jednoduché, stručné a přehledné (přinejmenším zdánlivě) právní úpravě těchto institutů $\mathrm{v}$ přestupkovém zákoně a správním řádu však nejen praxe, ale i související právní úpravy mohou přinášet a vyvolávat takové situace, které podstatu společného řízení výrazným způsobem zpochybňují a dosažení jimi sledovaného cíle a účelu značně komplikují, ne-li dokonce zcela vylučují.

Případem, kdy společné řízení ve spojení s absorpční zásadou nevede ke zmírnění dopadů potenciálně nepřiměřených správních trestů do právní sféry pachatele přestupku, je třeba situace, kdy je ve společném rrízení s podezřelým projednáváno více přestupků, z nichž však některé, byt' je za ně přestupce deliktně odpovědný, fakticky vyvolala jiná osoba, jejíž jednání není podezřelému přičitatelné a vi̊či níž následně může mít přestupce legitimní zájem uplatňovat regresní odpovědnost za jemu uloženou sankci. K tomu může dojít např́klad tehdy, kdy je maloobchodní prodejce (supermarket) trestán nejenom za - např́klad - prodej potravin s prošlým datem použitelnosti, ale zároveň i - opět př́kladmo - za prodej potravin nesplňujících obsahové složení deklarované na 
obalu. V obou případech jde o přestupky, ${ }^{1}$ které bude řešit tentýž správní orgán ${ }^{2}$ ve společném řízení (za předpokladu jejich souběžného spáchání, resp. zjištění).

Přestože prodejce je za oba tyto skutky deliktně odpovědný, je mezi nimi jasně patrný rozdíl v tom, do jaké míry mohl sám přestupce ovlivnit jejich vznik, resp. zabránit tomu, aby k nim došlo. Zatímco kontrola toho, zda nedochází k prodeji zboží s prošlým datem použitelnosti, se nachází ve sféře jeho, řekněme, „bezprostředního vlivu“, je faktické ověření souladu skutečného a deklarovaného obsahu potravinářského výrobku naproti tomu nejen zcela mimo reálné možnosti prodávajícího, ale hlavně jde primárně o povinnost samotného výrobce takové potraviny. Právě vůči němu pak může mít prodejce, který byl za skutek shledán deliktně odpovědným, legitimní zájem na uplatnění regresní odpovědnosti za škodu, která mu byla způsobena uložením správního trestu (typicky pokuty ${ }^{3}$ ).

Problém však nastává právě v okamžiku, kdy jsou oba výše zmíněné přestupky projednány $\mathrm{v}$ rámci společného řízení a je o nich rozhodnuto společným rozhodnutím za užití absorpční zásady. Přestože by vydání společného rozhodnutí a uložení jednoho úhrnného správního trestu mělo být vůči obviněnému příznivější (ve srovnání se dvěma samostatně uloženými pokutami), právě tento postup znemožní určení „míry“, v níž se na úhrnné pokutě každý z obou přestupků podílí, a v konečném důsledku tak i zjištění přesné výše škody potenciálně uplatnitelné vůči výrobci v rámci regresní odpovědnosti. To jistě není stav, který by byl „,ve prospěch“ přestupce.

Situaci nadto komplikuje i fakt, že př́ipadné dohodě na „odškodnění“ supermarketu dodavatelem potravin, již by obě strany v zájmu na zachování korektních obchodních vztahů třeba byly ochotny uzavřít i bez přesného vymezení výše škody (kterou by určily třeba konsensuálním kompromisem), brání právní úprava hospodářské soutěže, konkrétně v podobě zákona č. 395/2009 Sb., o významné tržní síle, v platném znění (dále také jen ,ZVTS“). Ten totiž neumožňuje prodejci - odběrateli zboží - požadovat po dodavateli zboží uplatnění náhrady za správní trest uložený mu kontrolním orgánem v přestupkovém řízení „,bez existence zavinění“, 4 tj. bez přesného prokázání výše škody vzniklé uložením pokuty, a to pod hrozbou spáchání dalšího přestupku s potenciálně značně citelným trestem. ${ }^{5}$

Je nabíledni, že nejde o zamýšlený efekt společného řízení o více přestupcích při aplikaci absorpční zásady za ukládání úhrnného správního trestu. Cílem tohoto příspěvku je zaměřit se na výše zmíněnou situaci, kdy tyto trestněprávní instituty mající působit ve prospěch obviněného ve skutečnosti nejen že nepůsobí žádoucím směrem, ale mohou dokonce vyvolávat důsledek přesně opačný, a též zamyslet se nad možnými argumenty a způsoby řešení tohoto problému.

1 Jde o přestupky podle $\S 10$ odst. 1 písm. a) a písm. b) zákona č. 110/1997 Sb., o potravinách a tabákových výrobcích, v platném znění (dále také jen „zákon o potravinách“).

2 Konkrétně pak místně př́slušná krajská veterinární správa, a to podle $\S 17$ odst. 2 písm. f) ve spojení s § 17 i odst. 1 písm. b) zákona o potravinách.

3 V daném př́ípadě až do výše 50 miliónů korun (dle § 17 odst. 2 písm. f) ve spojení s § 17 físm. d) zákona o potravinách).

4 § 4 odst. 2 písm. h) ZVTS.

5 Pokuta až do výše 10 miliónů korun nebo $10 \%$ z čistého obratu dosaženého odběratelem za poslední ukončené účetní období (§ 8 odst. 1 písm. a) ve spojení s $\S 8$ odst. 3 ZVTS). 


\section{SPOLEČNÉ ŘÍZENÍ O PŘESTUPCÍCH}

Společné řízení je jedním z již téměř tradičních institutů správního procesu. V obecné rovině je upraveno v § 140 zákona č. 500/2004 Sb., správní rád (dále také jen „Spగ̌ “), a ideově vychází patrně nejvíce z principu procesní ekonomie a hospodárnosti řízení (viz také $\S 6$ odst. $1 \mathrm{SpR}$ ) a zásady souladnosti dílčích postupů správních orgánů ( 8 odst. 1 SpŘ). Společné řízení umožňuje spojit do jednoho více správních ř́zení, k nimž je př́slušný tentýž správní orgán, pokud se týkají téhož předmětu (nebo spolu jinak věcně souvisejí) anebo se týkají týchž účastníků, nebrání-li tomu povaha věci (§ 140 odst. $1 \mathrm{SpŘ})$, což celý proces nejen zefektivňuje a zlevňuje, ale také výrazně eliminuje riziko vzniku neodůvodněných rozdílů v pojmově totožných (či obdobných) věcech.

Zvláštní úpravu společného řízení nacházíme - mimo jiné - v oblasti přestupkového práva. Již zákon č. 200/1990 Sb., o přestupcích (v posledním platném znění), stanovil, že jestliže se pachatel dopustil více přestupků, jejichž skutková podstata se týká porušení právních povinností vyskytujících se ve stejné oblasti veřejné správy ${ }^{6}$ a které je př́slušný projednávat týž orgán, projednávají se tyto přestupky ve společném řízení ( 57 odst. 1). V době svého vzniku, tedy v roce 1990, šlo o úpravu nejen zvláštní, ale také unikátní, nebot' tehdejší zákon č. 71/1967 Sb., o správním ř́zení (správní řád), coby obecná úprava správního řízení s procesním institutem společného řízení nepracoval. Od následně přijatého $\S 140 \mathrm{SpŘR} \mathrm{se} \mathrm{tato} \mathrm{úprava} \mathrm{lišila} \mathrm{především}$

- mírou své konkrétnosti - zákon o přestupcích výslovně předpokládal spáchání více přestupků jedním pachatelem, zatímco správní rád vcelku pochopitelně pracuje s obecnými pojmy („týž předmět (více rrízení)“, „titíž účastníci (více rízení)“ atp.),

- povinností provedení - zatímco správní rád pracuje toliko s fakultativním spojením více ř́izení do řízení společného (v rámci diskrečního oprávnění správního orgánu), v př́padě zákona o přestupcích nastávalo projednání sbíhajících se přestupků ve společném řízení obligatorně (ale s tím, že správní orgán rozhodující o přestupku disponoval pravomocí vyloučit řízení o jednotlivém skutku do samostatného řízení, a to za účelem urychlení rízení nebo z jiného důležitého důvodu) a

- způsobem vzniku společného řízení, tedy byly-li splněny podmínky, nastávalo v zákoně o přestupcích automaticky prrímo ex lege, na rozdíl od správního řádu, podle kterého ke spojení řízení dochází usnesením správního orgánu.

Někteří autoři při srovnání obou úprav došli k závěru, že ,úpravu správního řádu lze považovat za vhodnější, protože umožňuje více zohledňovat okolnosti daného př́ípadu a dává správnímu orgánu na zvážení, zda by bylo vedení společného řízení skutečně př́nosné, a to jak pro správní orgán, který př́ípad projednává, tak také pro účastníky řízení, ze kterého vyvodili, že „,vzhledem k tomu, že důvody pro vedení společného řizení jsou de facto obdobné ... a obecně se usiluje o odstraňování nadbytečných procesních odchylek, lze se domnívat, že úprava $\S 57$ je nadbytečná a bylo by ji možné

6 Podmínka, že se musí jednat o přestupky, ,,jejichž skutková podstata se týká porušení právních povinností vyskytujících se ve stejné oblasti veřejné správy“, byla do zákona o přestupcích zavedena až novelizací provedenou zákonem č. 204/2015 Sb., a platila tak pouze v období od 1. 10. 2015 do 30. 6. 2017. 
v budoucnu vypustit. Na škodu by pak určitě nebylo to, když by správní orgán získal rovněž v řízeních o přestupcích možnost volby, zda společné řízení vést nebo nikoli.“7

Nové přestupkové právo nicméně tyto hlasy nevyslyšelo. Ustanovení $§ 88$ zákona č. 250/2016 Sb., o odpovědnosti za přestupky a ř́zení o nich, v platném znění (dále také jen „přestupkový zákon“ či „PřestZk“), vychází z obdobné filozofie, kterou pro společné řízení užíval zákon o přestupcích. Společné přestupkové rrízení tedy stále zůstává obligatorní ${ }^{8}$, dopustil-li se podezřelý více přestupkủ (případně jde-li o vzájemně související přestupky více podezřelých), jejichž skutková podstata se týká porušení právních povinností vyskytujících se ve stejné oblasti veřejné správy, a k jejich projednání je věcně a místně příslušný týž správní orgán. Takové rízení opět nastává automaticky ze zákona (zahajuje se výhradně z moci úréední, a to doručením oznámení o zahájení rízení všem podezřelým z přestupku podle $\S 78$ odst. 2 PřestZk in fine) a správní orgán má opět toliko právo rozhodnout o prípadném vyloučení jednotlivého skutku do samostatného řízení za účelem urychlení řízení nebo z jiného důležitého důvodu.

Úprava ustanovení $\S 140$ správního řádu se pro společné řízení o přestupcích použije subsidiárně v těch záležitostech, které přestupkový zákon neupravuje (jako je např́íklad vedení jednoho správního spisu podle $§ 140$ odst. 5 SpŘ, stanovení formy usnesení pro vyloučení věci k samostatnému projednání podle $\S 140$ odst. 3 SpŘ, nebo třeba pravidla pro vydání společného rozhodnutí podle $\S 140$ odst. $7 \mathrm{Spr}^{9}$ atp.).

\section{ABSORPČNÍ ZÁSADA VE SPOLEČNÉM ŘÍZENÍ A JEJÍ DŮSLEDKY}

Zatímco vedení společného řízení je v zásadě ryze procesní otázkou nemající bezprostřední dopad do práv a povinností (obviněného) jako takových, je jedním z hmotněprávních důsledků, které se naopak do jeho právního postavení velmi podstatně promítnou, uplatnění specifických zásad při určování druhu a výše správního trestu za více spáchaných přestupků.

Přestupkový zákon zakotvuje pro souběh přestupků (projednávaných implicitně ve společném řízení) uplatnění dvou ze tří „klasických“ zásad uplatňovaných v českém právním řádu pro ukládání trestů za sbíhající se delikty. Zásadu kumulační (sčítací) obecná úprava přestupkového práva nezná, pracuje však - patrně - se zásadou absorpční (pohlcovací) upravenou v $\$ 41$ odst. 1 PřestZk a zásadou asperační (zostřovací) zakotvenou v navazujícím ustanovení $§ 41$ odst. 2 PřestZk.

Ona vyjádřená nejistota ohledně úpravy dvou zásad spočívá v tom, že řada autorů vyjadřuje důvodné pochyby o samotné použitelnosti oné asperační zásady na základě přestupkového zákona. Tyto pochybnosti vycházejí nejen z toho, že první dva odstav-

7 Obě citace JEMELKA, L. - VETEŠNÍK, P. Zákon o přestupcích a přestupkové ř́zení. Praha: C. H. Beck, 2013, s. 328.

8 A to i přesto, že judikatura dovodila, že jeho neprovedení nevyvolává bez dalšího nezákonnost rozhodnutí. Viz např́ílad rozsudek Nejvyššího správního soudu (dále jen „NSS“) ze dne 18. 6. 2009, čj. 1 As 28/2009-62.

9 Viz také např́íklad JEMELKA, L. - VETEŠNÍK, P. Zákon o odpovédnosti za přestupky a řizení o nich. Zákon o nékterých prestupcích. Praha: C. H. Beck, 2020, s. 718, 720. 
ce ustanovení § 41 PřestZk zakotvují dvě odlišné zásady pro určení druhu, resp. výše správního trestu, z nichž jedna - asperační - je vůči pachateli výrazně nepř́znivější, aniž by však bylo zákonem na jisto postaveno, kdy se má která z nich použít (přičemž vůči sobě nejsou ve vztahu obecnosti a zvláštnosti), ${ }^{10}$ ale také z toho, že úprava asperační zásady zůstala $v$ přestupkovém zákoně jako reziduum původní konstrukce tripartice přestupků (tj. rozdělení přestupků podle závažnosti na přestupky zvlášt' závažné, závažné a ostatní), která však nakonec nebyla realizována, aniž by se však ustanovení $\S 41$ odst. 2 PřestZk adekvátně upravilo, resp. zpřesnilo. ${ }^{11} \mathrm{~S}$ odkazem na pouhou fakultativnost uplatnění asperační zásady ${ }^{12}$ (ve srovnání s obligatorní aplikací zásady absorpční) si tak ve společném přestupkovém řízení, resp. při vydání společného rozhodnutí a ukládání úhrnného správního trestu patrně nevystačíme.

Klíčovou se tak pro trestání sbíhajících se přestupků stává právě zásada absorpční. Je však třeba přiznat, že správní právo jí nevěnuje výraznější pozornost a podrobnější rozbor této zásady tak v jeho teoretických pracích v zásadě nenacházíme. Do značné míry se na tomto faktu nepochybně projevuje skutečnost, že jde v prvé řadě o zásadu trestněprávní, která sice byla správním právem (trestním) z trestního práva aprobována, byt' teprve relativně nedávno, coby jeden z klíčových principů při rozhodování o vině a trestu, správní právo však nevykazuje zřetelnější ambice zabývat se možnými důsledky jejího uplatnění v rámci rozhodování o správních trestech.

\subsection{ABSORPČNÍ ZÁSADA V TEORII SPRÁVNÍHO PRÁVA}

To lze opřít i o zjištění, že řada administrativistů (včetně těch nejvýznamnějších) se problémem ukládání trestů za sbíhající se delikty vůbec nezaobírá, a ani v historii nezaobírala. Hoetzel o absorpční zásadě výslovně nehovoří (nepojmenovává ji), zmiňuje však ,zásadu o konkurenci trestných činů“ zakotvenou v tehdejším $§ 267$ zákona č. 117/1852 ř. z., o zločinech, přečinech a přestupcích, ${ }^{13}$ která absorpční zásadě do značné míry odpovídá. Toto ustanovení totiž zakotvilo pravidlo, podle nějž „Spáchal-li vyšetřovanec více přečinů nebo více přestupků, na něž se vztahuje totéž vyšetřování a odsouzení, anebo sejdou-li se takovým způsobem přečiny s přestupky, užívati se má toho zákona, který mezi těmito trestnými činy ustanovuje největší trest, avšak přihlížejíc i k činům ostatním. “ Hoetzel o této zásadě ve vztahu ke správnímu trestání uvádí, že je „sporné“, zda v této oblasti platí, a sám zastává názor, že ,ze zásadních důvodů nelze takové obdoby [tedy aplikaci této zásady trestního práva ve správním trestání - pozn. aut.] připustiti, “ na jehož základě se následně přiklání k nezbytnosti aplikace kumulativního principu ve správním trestání. To vysvětluje především růzností peněžních pokut ve správním trestání či růzností úřední kompetence trestajících správních orgánů. ${ }^{14}$

\footnotetext{
10 KOPECKÝ, M. Správní právo, obecná část. Praha: C. H. Beck, 2019, s. 284.

11 PRÁŠKOVÁ, H. Nové prestupkové právo. Praha: Leges, 2017, s. 264. Patrně odlišný názor viz SLÁDEČEK, V. Obecné správní právo. 4. vyd. Praha: Wolters Kluwer, 2019, s. 210 či MATES, P. a kol.: Základy správního práva trestního. Praha: C. H. Beck, 2017, s. 110.

12 JEMELKA - VETEŠNÍK, 2020, c. d., s. 341.

13 Všimněme si tehdejšího ještě velmi neostrého rozlišení mezi správním (resp. policejním) deliktem a trestným činem.

14 HOETZEL, J. Československé správni právo, část všeobecná. Praha: Melantrich, 1937, s. $374,375$.
} 
I v př́ípadě tzv. trestního finančního práva ${ }^{15} \mathrm{v}$ podobě trestního zákona důchodkového z roku 1835, který platil až do doby první republiky, se primárně uplatňovala zásada kumulační („mají býti tudíž zákonné tresty určeny pro každý přestupek samostatně“) a pohlcování (absorpce) trestů bylo pouze výjimkou (,při konkurenci více deliktů, které všechny jsou trestány vězením; trest se stanoví podle přestupku, na nějž je uložena sazba nejvyšší, popř. trest nejpřísnějši‘“16).

Pošvář připomíná dokonce i možnost kumulace trestu za trestný čin („soudní přestupek“) a správní delikt, jde-li o jednání naplňující zároveň skutkovou podstatu obou druhů těchto deliktů. To dokládá na př́íkladu čl. 3 odst. 2 zákona č. 125/1927 Sb. z. a n., o organisaci politické správy, podle kterého mohou politické úřady ukládat tresty za „Všeliké nepř́ístojné jednání nebo chování na místech veřejných nebo veřejně př́ístupných, kterým se ruší neb ohrožuje veřejný - pořádek, klid, bezpečnost, dobrý mrav nebo slušnost nebo se vzbuzuje veřejné pohoršení“, a to „bez újmy soudního stíhání““ ${ }^{17}$ Zároveň však na základě nařízení ministerstva vnitra, spravedlnosti a nejvyššího úřadu policejního č. 198/1857 ř. z. (v dobách první republiky patrně stále platného) platilo pravidlo, že „nikdy nesmí býti uložen vy̌šsí trest než ten, který by byl nejnižší, kdyby čin měl povahu přečinu nebo přestupku podobného druhu ve smyslu všeobecného trestního zákona." 18

Ke kumulačnímu principu se později hlásí i Červený, který ještě v 80. letech uvádí, že: „Protože platné právo neupravuje speciálně ukládání trestů při souběhu přestupků [má na mysli ,obecnou úpravu' tehdy platného přestupkového práva - pozn. aut.], ukládá se trest za každý přestupek zvlášt'. To platí jak o souběhu vícečinném (pachatel spáchal více přestupků dřive, než o některém z nich bylo rozhodnuto), tak o souběhu jednočinném (jednání pachatele má znaky několika přestupků). Platné právo přijalo koncepci tzv. sčítací zásady.“19

S absorpční zásadou tak výslovně pracuje až teorie porevoluční. Prášková s tímto pojmem pracuje od prvního vydání Hendrychovy učebnici a vztahuje jej k zákonu o přestupcích ${ }^{20}$ (tehdy ještě značně mladému), $\mathrm{v}$ čemž pokračuje po celou dobu platnosti tohoto předpisu. ${ }^{21}$ Stejný princip, byt' bez výslovného pojmenování, uvádí v téže době i brněnská doktrína, ${ }^{22}$ která též na tomto svém postoji konstantně setrvá. ${ }^{23}$ Ve vztahu

15 Dělení veřejnoprávních deliktů, resp. deliktního či trestního práva, na soudní, správní (,„policejní“) a finanční vycházelo již z § 95 zákona č. 121/1920 Sb. z. a n., Ústavy Československé republiky. Ten stanovil, že „soudní moc ve věcech trestních přísluší občanským soudům trestním, pokud není zvláštním zákonem přikázána trestním soudům vojenským, nebo pokud věci tyto nemají býti podle všeobecných předpisů projednávány v trestním řízení policejním nebo finančním“.

16 Obě citace SIBLÍK, J. Trestní právo a řízení důchodkové. In: HÁCHA, E. - HOETZEL, J. - WEYR, F. LAŠTOVKA, K. Slovník veřejného práva československého. Svazek IV. Brno: Polygrafia, 1938, s. 954.

17 POŠVÁ̌̆, J. Nástin správního práva trestního. Studie o některých pojmech, zejména o vině. Praha Brno: Orbis, 1936, s. 59.

18 POŠVÁ̉̆, J. Nástin správniho práva trestniho II. O administrativních trestech a správním trestním řizení. Brno: Nákladem Čsl. akademického spolku „Právník“, 1946, s. 35, 123.

19 LUKEŠ, Z. a kol. Československé správni právo, obecná část. Praha: Panorama, 1981, s. 195.

20 HENDRYCH, D. a kol. Správní právo, obecná část. Praha: C. H. Beck, 1993, s. 97.

21 V prakticky nezměněné podobě průběžně až do 9. vydání předmětné učebnice (2016, s. 307).

22 PRŮCHA, P. Základy správního práva a veřejné správy, obecná část. Brno: MU, 1994, s. 235.

$23 \mathrm{~V}$ prakticky nezměněné podobě průběžně až do 8. vydání předmětné učebnice (2012, s. 402). 
k aktuální úpravě přestupkového práva pak absorpční zásadu nejnověji vymezuje i Kopeckého učebnice. ${ }^{24}$

Podrobnější vymezení absorpční zásady však neposkytují ani specializované učebnice správního práva trestního. Mates ji toliko konstatuje ${ }^{25}$ (přičemž v souladu s judikaturou dovozoval její použití ještě na základě zákona o přestupcích i pro potřeby tehdejších ostatních správních deliktů ${ }^{26}$ ), Prášková pak v monografii o novém přestupkovém právu vymezuje absorpční zásadu především její základní charakteristikou, nicméně bez podrobnější analýzy její podstaty a fungování (,zásada absorpční, podle které správní orgán uloží správní trest podle ustanovení vztahujícího se na přestupek nejpřísněji trestný“ ${ }^{\text {‘27}}$ ). O něco podrobněji ji rozebírá v jednom ze svých sborníkových př́spěvkủ (zaměřeném také, ale ne pouze, na tuto zásadu). ${ }^{28}$

Překvapivě jen o málo detailnější je odborný výklad $\mathrm{k}$ trestnímu zákoníku, v němž Púry dovozuje, že absorpční zásada spočívá „,... v tom, že větší (přísnější, delší) trest ,pohlcuje' menší (mírnější, kratší) trest. Sbíhající se trestné činy jsou tedy postiženy pouze trestem stanoveným za nejtěžší z nich a u všech mírnějších trestných činů v podstatě jde o upuštění od potrestání." ${ }^{29}$ Stejný závěr zastávala teorie trestního práva již ve vztahu k předchozímu trestnímu zákonu. ${ }^{30}$

Prakticky totéž pak uvádí Právnický slovník: „Absorpční princip trestání je jedním ze tří základních principů (vedle asperačního a kumulačního), který se užívá pro ukládání trestu, jestliže se pachatel odsuzuje za více trestných činů (souběh trestných činů). Podle českého trestního zákoníku, ale i zákona o soudnictví ve věcech mládeže, je tento princip základním a je pouze doplněn prvky asperačního a kumulačního principu. Odsuzuje-li soud pachatele za dva nebo více trestných činů, uloží mu úhrnný trest podle toho ustanovení, které se vztahuje na trestný čin z nich nejpř́ísněji trestný (§ $43 \mathrm{TrZ}$ ). Stejný princip platí při ukládání souhrnného trestu. Př́isnější (větší) trest tak pohlcuje (absorbuje) tresty menší (poena maior absorbetminorem).“31

\subsection{ABSORPČNÍ ZÁSADA V JUDIKATUŘE SPRÁVNÍCH SOUDU゚}

Obšírněji se dílčími aspekty absorpční zásady zabývá až soudní judikatura. Ta z hlediska jejího použití zdůrazňuje, že použití této zásady je při správním trestání (včetně trestání deliktů vyplývajících např́iklad z práva Evropské unie ${ }^{32}$ ) povinné, a to i kdyby se tak mělo stát „pouze“ na základě analogie s trestním právem, protože je

24 KOPECKÝ, 2019, c. d., s. 283.

25 MATES, 2017, c. d., s. 109.

26 MATES, P. a kol.: Základy správního práva trestního. Praha: C. H. Beck, 2010, s. 40.

27 PRÁŠKOVÁ, 2017, c. d., s. 140, 141.

28 PRÁŠKOVÁ, H. Ukládání sankcí při souběhu správních deliktů. In: NOVOTNÝ, O. (ed.): Pocta Vladimíru Mikule k 65. narozeninám. Praha: ASPI, 2002, s. 317 a násl. (zejm. s. 318 a násl.).

29 ŠÁMAL, P. - GŘIVNA, T. - HERCZEG, J. - KRATOCHVÍL, V. - PÚRY, F. - RIZMAN, S. - ŠÁMALOVÁ, M. - VÁLKOVÁ, H. - VANDUCHOVÁ, M. Trestní zákoník (EVK). Komentár̆. Praha: C. H. Beck, 2012, s. 584.

30 ŠÁMAL, P. - PÚRY, F. - RIZMAN, S. Trestní zákon. Komentář. Praha: C. H. Beck, 2004, s. 301.

31 GŘIVNA, T. Absorpční princip trestání. In: HENDRYCH, D. - BĚLINA, M. - FIALA, J. - ŠÁMAL, P. - ŠTURMA, P. - ŠTENGLOVÁ, I. - KARFÍKOVÁ, M. Právnický slovník. Praha: C. H. Beck, 2009.

32 PETR, M. Mezinárodní kartely: více trestů za jedno jednání? Právní rozhledy, 2008, č. 8, s. 287-294. 
principem uplatňovaným ve prospěch delikventa. ${ }^{33}$ Naopak zásada kumulativní je při stanovení správního trestu nepř́ípustná, ${ }^{34}$ a to i v prŕípadě, že by správní orgán přiřadil ke každému deliktu shodnou výši pokuty, jako kdyby o tomto deliktu rozhodoval samostatně, a následně tyto částky sečetl, i kdyby nepřekročil horní hranici zákonného rozpětí. ${ }^{35} \mathrm{Z}$ procesního hlediska přitom na povinnosti uplatnění absorpční zásady nic nemění ani to, že by při trestání souběhu více deliktů nebylo $-\mathrm{v}$ zásadě $\mathrm{z}$ jakéhokoliv důvodu - vedeno společné ř́izení. ${ }^{36}$

Co do důsledků použití této zásady vycházejí správní soudy z toho, že podstata absorpční zásady tkví v absorpci sazeb (tedy př́snější trest pohlcuje mírnější), princip tak dopadá výhradně do sféry rozhodnutí o trestu - absorpční zásada nic nemění na tom, že delikvent je uznán vinným ze spáchání více deliktů. ${ }^{37}$ Správní orgán tedy vyměří pokutu za jeden ze sbíhajících se deliktů a zároveň v rámci hodnocení závažnosti jednání přihlíží jako $\mathrm{k}$ přitěžující okolnosti i $\mathrm{k}$ tomu, že bylo spácháno více deliktů. Celkovou výši pokuty pak musí ve svém rozhodnutí i z tohoto hlediska samožrejmě náležitě odůvodnit. ${ }^{38}$

Správní orgán při tom však nestanovuje samostatné pokuty za jednotlivé delikty a netvoří výsledný trest součtem ,dílčích pokut“ (takový postup by totiž mohl znamenat i to, že za jediné protiprávní jednání by bylo možno uložit i sankci přesahující zákonem stanovenou horní hranici). ${ }^{39}$ Musí však oné přitěžující okolnosti v podobě sbíhajících se deliktů přiřadit patřičnou hodnotu, byt' třeba jen abstraktně vyjádřenou; pokud by uvedl pouze to, že $\mathrm{k}$ této okolnosti prihlédl, ale neuvedl by jak, stalo by se takové tvrzení do značné míry neurčité a $\mathrm{v}$ důsledku toho i nepřezkoumatelné. ${ }^{40}$ Správní orgán následně uloží jeden správní trest určený podle nejpř́sněji trestného deliktu, přičemž u mírnějších deliktů, jejichž tresty jsou aplikací této zásady absorbovány, se v zásadě jedná o upuštění od potrestání. ${ }^{41}$

33 Rozsudek NSS ze dne 18. 6. 2009, čj. 1 As 28/2009-62, rozsudek NSS ze dne 22. 9. 2005, čj. 6 As 57/2004-54 a rozsudek NSS ze dne 23. 2. 2006, čj. 6 As 17/2005.

${ }^{34}$ Ledaže by ji zákon výslovně stanovil. Tak tomu bylo např́íklad v ustanovení $§ 40$ odst. 15 dnes již zrušeného zákona č. 86/2002 Sb., o ochraně ovzduší.

35 Rozsudek NSS ze dne 31. 10. 2008, čj. 5 Afs 9/2008-328.

36 Rozsudek NSS ze dne 18. 6. 2009, čj. 1 As 28/2009-62.

37 Rozsudek NSS ze dne 23. 2. 2006, čj. 6 As 17/2005-51. Cit. dle JEMELKA, L. - VETEŠNíK, P. - LIBOSVÁR, O. Zákon o kontrole. Praha: C. H. Beck, 2014, s. 144. Shodně viz též i JEMELKA - VETEŠNÍK, 2013, c. d., s. 70.

38 Rozsudek NSS ze dne 3. 12. 2008, čj. 7 Afs 7/2008-200.

39 Rozsudek Vrchního soudu v Praze ze dne 22. 12. 1995 sp. zn. 6 A 216/93 (cit. dle rozsudku NSS ze dne 15. 8. 2012, čj. 6 As 3/2011-119).

40 Rozsudek NSS ze dne 25. 1. 2006, čj. 4 As 22/2005-68 (citováno i za pomoci VACEK, P. Judikatura Nejvyššího správního soudu: správní delikty. Soudní rozhledy, 2006, č. 7, s. 245-248).

41 KOUDELA, R. Opomíjené možnosti faktické konzumpce. Trestněprávní revue, 2015, č. 9, s. 215-216. Upuštění od potrestání je zde patrně třeba vnímat zejména procesněprávně, nebot' z hlediska hmotného práva stále platí, že úhrnný trest je ukládán za všechny sbíhající se delikty, a tedy i všechny tyto delikty jsou trestány. 


\section{ARGUMENTY K MOŽNÉMU „PROLOMENÍ“ NEŽÁDOUCÍHO DŮSLEDKU ABSORPČNÍ ZÁSADY VE SPOLEČNÉM ŘÍZENÍ}

Je patrné, že v důsledku uvedené charakteristiky absorpční zásady a jejích aplikačních dopadů $\mathrm{v}$ rámci společného řízení nemají správní orgány povinnost, ale v zásadě ani možnost ve svých rozhodnutích rozlišit, která „,část“ úhrnného trestu byla uložena za který ze sbíhajících se deliktů, resp. přesněji specifikovat výši trestů za ty delikty, které nejsou nejpř́sněji trestné a jejichž tresty pohlcovány (absorbovány) trestem nejpřísnějším. Výše zmíněné komplikace spojené s uplatněním regresní odpovědnosti přestupce (supermarketu) vůči tomu, kdo primárně porušil svou právní povinnost, a způsobil tak přestupek (výrobce, resp. dodavatel potravin), tak vycházejí ze samotné podstaty absorpční zásady a jejích základních vlastností. Ty však zejména v kombinaci s úpravou ochrany hospodářské soutěže zjevně působí přesně opačně, než jak by měly, tj. nikoliv ve prospěch obviněného, ale naopak k jeho tíži.

Otázka tedy zní, kterou argumentační cestou se vydat při řešení tohoto problému a zda vůbec nějaká taková „schůdná“ cesta existuje. Je totiž patrné, že zejména vlastnosti absorpční zásady a její podoba vycházejí již z desítek let zažitých koncepcí a teorií zejména $\mathrm{v}$ oblasti trestního práva a správní právo tak zpravidla „nemá sílu“ pro své potřeby takto zásadně modifikovat právní instituty převzaté z jiných právních oborů.

Přesto se zdá, že zájem přestupce, který ztratil - v důsledku pohlcení trestů za méně závažné přestupky, za které sice odpovídá, ale které nezpůsobil - možnost uplatnit regresní odpovědnost, je natolik legitimní, že prostor pro alespoň určitou úpravu aplikační praxe by zde existovat mohl, či přinejmenším měl.

\subsection{VYČLENĚNÍ ROZHODNUTÍ O DÍLČÍM PŘESTUPKU DO SAMOSTATNÉHO ŘÍZENÍ}

Ryze procesním řešením celého problému by samozřejmě mohlo být vyčlenění rozhodnutí o přestupku, který byl „primárně způsoben“ jednáním osoby odlišné od přestupce (zjednodušeně řečeno), vůči níž by tento mohl mít zájem na uplatnění regresní odpovědnosti, do samostatného rrízení. Učinit tak může správní orgán za účelem urychlení rízení, prrípadně ,z jiného důležitého důvodu“ ( 88 odst. 5 PřestZk), v zásadě kdykoliv až do okamžiku vydání (společného) rozhodnutí, a to nejen z důvodů předpokládaných (identifikovatelných) správním orgánem samotným, ale také „,z jiných důležitých důvodů“ tvrzených a prokázaných účastníky rrízení, zde tedy především obviněným.

Zákon onen ,jiný důležitý důvod“ blíže nespecifikuje a ani komentářová literatura $\mathrm{k} \S 88$ odst. 5 PřestZk ${ }^{42}$ či třeba $\mathrm{k} \S 140$ odst. $3 \mathrm{Spr}{ }^{43}$ který tento pojem používá ze stejného důvodu, jej podrobněji nerozvádí. Jde o klasický tzv. neurčitý právní pojem. ${ }^{44}$

42 JEMELKA - VETEŠNÍK, 2020, c. d., s. 720.

43 Viz např́íklad VEDRAL, J. Správní ř́ád. Komentář. Praha: Bova Polygon, 2012, s. 1070, 1071, či třeba JEMELKA, L. - PONDÉLÍĆKOVÁ, K. - BOHADLO, D. Správní ŕád. Praha: C. H. Beck, 2019, s. 743, 744.

44 Viz také např́íklad KOPECKÝ, 2019, c. d., s. 52 a 53. 
Tímto ,jiným důležitým důvodem“, pro který by bylo možné vyčlenit rozhodnutí o konkrétním přestupku do samostatného řízení, by tedy mohl být právě i zájem přestupce na zachování možnosti následného uplatnění regresní odpovědnosti vůči tomu, kdo porušením své „primárni“" právní povinnosti následný přestupek (spolu)způsobil. Vycházíme-li z toho, že vedení společného řízení za současného uplatnění absorpční zásady mají působit ve prospěch obviněného, pak vedou-li v daném př́padě oba tyto instituty $\mathrm{k}$ efektu přesně opačnému, nebylo by $\mathrm{v}$ rozporu s jejich podstatou ustoupit od jejich uplatnění.

Sám přestupkový zákon kromě jiného umožňuje, resp. ukládá přestupkovému orgánu zohlednit při stanovení výše a druhu trestu i to, ,že o některém z více přestupků, které byly spáchány jedním skutkem nebo více skutky, nebylo rozhodnuto ve společném řízení“ ( 37 písm. b) PřestZk). Zákon tím sice mírí patrně zejména na situaci, kdy nelze vést společné ř́zení o přestupcích, a to třeba $\mathrm{z}$ toho důvodu, že nejde o přestupky „ve stejné oblasti veřejné správy, a k jejich projednání je př́slušný týž správní orgán“ ( $\$ 88$ odst. 1 PřestZk), a přesto je třeba uplatnit absorpční zásadu, ${ }^{45}$ nic však zřejmě nevylučuje, aby byl stejný princip uplatněn i v př́padě ,jiného důležitého důvodu“, pro který by bylo vedení společného rízení nežádoucí (nebot' by ve svých důsledcích vedlo $\mathrm{k}$ aplikaci absorpční zásady v neprospěch obviněného).

\subsection{ABSORPCE TRESTUீ, NIKOLIV „CELÝCH“DELIKTU゚}

Jak vyplývá z výše uvedených charakteristik, uplatnění absorpční zásady znamená absorpci správních trestů, nikoliv přestupků jako takových. Jak konstatoval i NSS, uplatnění absorpční zásady ,... tkví v absorpci sazeb (tedy př́ísnější trest pohlcuje mírnější). Sbíhající se delikty jsou tak postiženy pouze trestem stanoveným pro nejtěžší z nich, což při stejných sazbách pokut znamená, že správní orgán posoudí závažnost deliktu a úhrnný trest uloží podle sazby za nejzávažnější z těchto deliktů... Použití této zásady tedy má místo při stanovení konkrétní výměry úhrnné sankce, což nic nemění na tom, že delikvent bude uznán vinným ze spáchání více správních deliktů.“46

Pokud NSS předpokládá - a to zcela souladně s teorií - že absorpční zásada vyžaduje, aby byl pachatel uznán vinným ${ }^{47}$ ze spáchání každého jednotlivého správního deliktu (a v enunciátu rozhodnutí je povinen uvést a přesně vymezit všechny tyto delikty, jichž se pachatel dopustil ${ }^{48}$ ), bylo by legitimní po správním orgánu požadovat, aby tuto nezbytnou vinu obviněného a s ní spjatý potenciální (jakkoliv jen hypotetický) trest za každý delikt určitým způsobem kvantifikoval. Mělo by být nerozhodné, že tento trest ukládán nebude, či - lépe řečeno - že o něm nebude samostatně rozhodováno. Jde však o přitěžující okolnost, která musí být stanovena najisto a dostatečně přesně a konkrétně, aby mohla být správně aplikována.

45 Viz například rozsudek NSS ze dne 18. 6. 2009, čj. 1 As 28/2009-62.

46 Rozsudek NSS ze dne 22. 9. 2005, čj. 6 As 57/2004-54.

47 Viz také TOMAN, A. Kárná odpovědnost exekutorských kandidátů a koncipientů - část druhá. Komorní listy, 2012, č. 4, s. 12-19.

48 MATES, P. Disciplinární odpovědnost podle zákona o státní službě. Trestněprávní revue, 2015, č. 4, s. $87-90$. 


\subsection{NEZBYTNOST PŘESNÉHO ODU゚VODNĚNÍ DISKREČNÍHO OPRÁVNĚNÍ}

Povaha institutu správního uvážení při stanovení druhu a výše správního trestu imanentně vyžaduje, aby jeho použití bylo spojeno s podrobným a jasným odůvodněním, které jednoznačně a přesně umožní zpětně identifikovat a zhodnotit postup správního orgánu a důvodů, které jej vedly ke konkrétnímu rozhodnutí. ${ }^{49}$ Tento argument - požadavek odůvodnění coby obsahové náležitosti správního rozhodnutí - by sám o sobě vystačil na samostatné pojednání, níže se proto omezím jen na jeho nejzákladnější kautely. ${ }^{50}$

K odůvodnění správního rozhodnutí v případě užití diskrece dovodila například judikatura, že správní orgán si při uplatňování správního uvážení nemůže počínat zcela libovolně; to by bylo v rozporu s charakterem státní správy jako činnosti podzákonné a zákonem řízené. Determinace správního uvážení zákonem však neznamená jeho úplnou negaci. Zákon vytváŕí kritéria, podle nichž a v jejichž rámci se může uskutečnit volba včetně výběru a zjišt'ování těch skutečností konkrétního případu, které nejsou správní normou předpokládány, ale uvážením správního orgánu jsou uznány za potřebné pro volbu jeho rozhodnutí. ${ }^{51}$

Rubem diskrečního oprávnění správního orgánu je povinnost správního orgánu volné úvahy užít, tedy zabývat se všemi hledisky, které zákon jako premisy takové úvahy stanoví, opatřit si za tím účelem potřebné důkazní prostředky, provést jimi důkazy, vyvodit z těchto důkazů skutková a právní zjištění a poté volným správním uvážením, nicméně při respektování smyslu a účelu zákona a mezí, které zákon stanoví, dospět při dodržení pravidel k dalším, v zákoně přímo neuvedeným, leč pro projednávaný případ významným. Nevyjádří-li se správní orgán k otázce výše pokuty v odůvodnění svého rozhodnutí zákonem požadovaným způsobem, jde o pochybení, mající za následek zrušení žalobou napadeného rozhodnutí. ${ }^{52}$

Rozhodnutí o uložení pokuty je třeba odůvodnit tak, aby z něj bylo patrno, na základě jakých úvah dospěl správní orgán ke stanovení konkrétní výše pokuty, a zda a v jakém rozsahu vzal v úvahu hlediska stanovená zákonem - nestačí tedy např́. pouhý odkaz na to, že pokuta byla vyměřena v zákonných mezích. Pokud správní orgán takový postup nerespektuje, je jeho rozhodnutí nepřezkoumatelné pro nedostatek důvodů a jako takové bude zrušeno. Ústavní soud v této souvislosti konstatoval, že nedostatek patřičného odůvodnění je v rozporu s právem na spravedlivý proces podle čl. 36 odst. 1 LPS. ${ }^{53}$ Mates k tomu dále dodává: „V př́ípadě, že zákon taková kritéria neobsahuje, je výše pokuty věcí volné úvahy správního orgánu, který ovšem musí respektovat obecné požadavky kladené na volné uvážení (např. princip rovnosti účastníků řízení a zásadu, že ve skutkově shodných či podobných případech nemají vznikat nedůvodné rozdíly). Současně je vždy míra jeho volnosti omezena zákazem libovůle plynoucí pro všechny orgány

49 Za mnohé viz např́íklad rozsudek NSS ze dne 31. 3. 2004, čj. 5 A 154/2002-51.

50 Viz například HENDRYCH, 2016, c. d., s. 61 a 62.

51 Rozsudek Nejvyššího soudu ČR ze dne 15. 10. 1992, čj. 6 A 6/92-3.

52 Rozsudek Vrchního soudu v Praze ze dne 5. 11. 1993, sp. zn. 6 A 99/92.

53 Například rozsudky NSS čj. 8 As 1/2006-136, 4 As 34/2004-53 a 8 As 13/2006-115; nález Ústavního soudu III. ÚS 84/94 a řada dalších; viz též Doporučení Rady ministrů Rady Evropy (80) 2 o správním uvážení. Cit. dle MATES a kol., 2010, c. d., s. 34, 35. 
veřejné moci z principů demokratického a právního státu, která by odporovala postavení veřejné správy, jakožto podzákonné a zákonem řízené činnosti. V demokratickém právním státě totiž neexistuje absolutní volná úvaha v tom smyslu, že by správní orgán nebyly při svém rozhodování vázány vưbec žádnými kritérii. Vždy jsou povinny respektovat minimálně takové principy, jako je rovnost, zákaz diskriminace, princip proporcionality a další, plynoucí z Ústavy, mezinárodních smluv a obecných zásad správního práva. Diskreční oprávnění není pouze právem, ale také povinností a správní orgán si musí opatřit všechny podklady, provést důkazy a vyvodit $\mathrm{z}$ nich př́islušné závěry při respektování smyslu a účelu zákona a mezí, které zákon stanoví, a na tomto základě dospět k adekvátnímu rozhodnutí. “54

V neposlední řadě nelze nezmínit ani evropské standardy výkonu veřejné správy tvořené typicky (byt' nikoliv výlučně) acquis communautaire, tj. unijním právem př́ípadně doplňovaným doporučeními Rady Evropy. Z těch lze zmínit zejména Doporučení Výboru ministrů Rady Evropy R (91) 1, o správních sankcích, či Rezoluci Výboru ministrů Rady Evropy (77) 31, o ochraně jednotlivců ve vztahu ke správním aktům, ze kterého vyplývá například to, že rozhodnutí, jímž se ukládá sankce, musí být řádně odůvodněno..$^{55}$ Jak shrnuje např́íklad Pomahač, „z uvedených aktů, z navazující judikatury Evropského soudu pro lidská práva i z judikatury našeho Ústavního soudu (srov. např. nálezy sp. zn. III. ÚS 611/01, sp. zn. II. ÚS 788/02 a sp. zn. I. ÚS 1849/08) a judikatury správních soudů (zejména rozsudek NSS čj. 8 As 17/2007-121, dále též usnesení Vrchního soudu v Praze sp. zn. 6 A 86/2000 (S 736-SJS 1/2001), rozsudek NSS čj. 7 A 17/2002-34, rozsudek NSS čj. 6 As 57/2004-54, rozsudek NSS čj. 5 A 164/2002-44) v podstatě vyplývá, že základní principy vztahující se na soudní trestání je třeba respektovat i v oblasti správního trestání“ ${ }^{56}$

\subsection{PRAVIDLA SOUTĚŽNÍHO PRÁVA}

Již bylo zmíněno, že jednou z překážek uplatnění regresní odpovědnosti mohou být i pravidla vyplývající ze soutěžního práva, konkrétně pak ze ZVTS. Pokud je trestaným přestupcem napríklad právě odběratel ve smyslu tohoto zákona, a tím, jehož jednáním byl přestupek ,primárně způsoben“, je jeho dodavatel (typicky výrobce potraviny), stojí uplatnění regresní odpovědnosti v cestě překážka nejen v podobě nejasné výše požadované náhrady (za trest absorbovaný v rámci společného rozhodnutí o více přestupcích), ale také v podobě striktního požadavku na jednoznačném prokázání „zavinění“ dodavatele na uloženém trestu.

To je však pro odběratele - prodejce - překážka jen obtížně překročitelná, a to navzdory tomu, že komentáŕová literatura výslovně uvádí nejen to, že ,je současně legitimní a spravedlivé, aby odběratel smluvně přenesl náklady na jemu uloženou pokutu na př́slušného dodavatele pro př́ípady, kdy bude pokutovaný za určitý delikt např. na úseku kvality potravin, který sice bude zjištěný v jeho provozovně, nicméně jeho původní prríčina bude již na straně dodavatele“, ale také to, že „dané ustanovení nemá být

\footnotetext{
MATES a kol., 2010, c. d., s. 35.

Viz také MATES a kol., 2010, c. d., s. 45.

66 HENDRYCH a kol., 2016, c. d., s. 294, 295.
} 
vykládáno tak, že vyžaduje zavinění dodavatele ve vztahu k př́slušnému porušení veřejnoprávní povinnosti. Ve vztahu k ní je dle našeho názoru dostačující, že její porušení má původní prríčinu $\mathrm{v}$ jednání nebo opomenutí dodavatele. Jinak řečeno, je přičitatelné dodavateli.“"57

Přestože tedy odborná interpretace zákona o významné tržní síle je ještě méně rigidní, než by - potenciálně - mohla být (navzdory výslovné zákonné úpravě výklad nepožaduje prokázání „,zaviněni“'), je patrné, že přestupce nemusí být v př́padě potrestání za přestupky úhrnným trestem ani za takovéhoto „méně př́ísného“ výkladu schopen uplatnit svá práva vůči dodavateli, který porušil svou povinnost. Vydání společného rozhodnutí ve společném řízení o více přestupcích za uplatnění absorpční zásady sice zachovává povinnost správního orgánu přesně vymezit všechny delikty, způsob jejich spáchání a skutek, který je pod př́íslušnou skutkovou podstatu přestupku subsumován (tj. ona „přičitatelnost dodavateli“), neumožňuje však rozpoznat výši této přičitatelnosti, resp. přiřadit konkrétní část pokuty („míry odpovědnosti“) jednání konkrétního dodavatele.

Právní řád by měl být jednotným, vnitřně bezrozporným a organicky logickým celkem. Zdá se být proto ve zřejmém rozporu s tímto požadavkem (opakovaně zdůrazněním v desítkách rozhodnutí nejvyšších orgánů soustavy soudní moci), pokud by správní orgán při rozhodování, zda užít či neužít absorpční zásadu, resp. zda vyčlenit či nevyčlenit ř́zení o jednom z přestupků do samostatného řízení (viz $§ 88$ odst. 5 PřestZk), nebral v potaz důsledky, které z ní pro obviněného vyplývají z dalších právních předpisů.

\section{ZÁVĚR}

Teorie trestního i správního práva jsou zcela jednotné v názoru, že absorpční zásada představuje princip působící ve prospěch obviněného. Správní orgán by ji však neměl aplikovat „,bezhlavě“ s automatickým předpokladem, že tato zásada vždy zapůsobí „ve prospěch obviněného“ sama od sebe. Okolnosti zmíněné v tomto př́spěvku zmíněné představují zcela zásadní faktory měnící povahu dopadů absorpční zásady do právní sféry obviněného, a to ze zásady, které má být $\mathrm{v}$ jeho prospěch, na zásadu působící vůči němu zřetelně nepř́íznivě.

Argument, že výhoda jejího uplatnění pro obviněného stále spočívá v tom, že absorpce trestů za více přestupků sníží celkovou částku vyjádřenou úhrnně stanovenou pokutou (ve srovnání s př́padnou kumulací jednotlivě uložených dílčích pokut), obstojí pouze do té míry, do jaké jde v daném př́padě o přestupky (ne)přičitatelné jiným subjektům, než je obviněný. Není obtižné si představit situaci, kdy supermarket coby obviněný bude potrestán úhrnnou pokutou za 10 přstupků, z nichž však třeba celých 8 bude přičitatelných jeho jednotlivým dodavatelům, vůči nimž však vyvození regresní odpovědnosti nebude možné z důvodu užití absorpční zásady. Takový postup jednoznačně nelze považovat za „ve prospěch obviněného“.

57 KINDL, J. - KOUDELKA, M. Zákon o významné tržní síle. Praha: C. H. Beck, 2017, s. 106. Autoři zde onou ,přičitatelností“s největší pravděpodobností nemají na mysli přičitatelnost ve smyslu deliktní odpovědnosti právnické osoby, nebot’ ta nade vši pochybnost leží na bedrech odběratele (prodejce). 
Tento text neměl ambice zabývat se všemi aspekty, které jsou či mohou být spjaty s otázkami společných řízení o přestupcích a aplikací absorpční zásady při správním trestání. Z hmotněprávních aspektů, které zde byly - nebot' z tematických a prostorových důvodů musely být - záměrně opomenuty, lze namátkou zmínit třeba problém ne vždy zcela jednoznačného určování onoho „nejpřísněji trestného přestupku“, za který se ve společném ř́zení ukládá úhrnný správní trest. Administrativní procesualisty by zase jistě mohla zajímat třeba otázka (ne)možnosti vyřízení některého ze současně zjištěných přestupků (např́iklad v rámci správně-dozorčí činnosti) ve zkráceném, typicky př́ikazním, přestupkovém řízení a důsledků takového kroku ve vztahu $\mathrm{k}$ absorpční zásadě a dalším principům spravedlivého procesu a správního trestání ${ }^{58}$ Tyto a jistě i mnohé další otázky by nepochybně mohly a měly být předmětem dalších odborných pojednání.

JUDr. PhDr. Jan Malast, Ph.D.

Fakulta právnická Západočeské univerzity v Plzni

janmal@ksp.zcu.cz

58 Aktuálnost této materie dokládá i jeden z nejnovějších příspěvků ve Sbírce rozhodnutí NSS, konkrétně pak pod č. 3963/2020. Zdroj: http://sbirka.nssoud.cz/cz/spravni-trestani-zasada-absorpce.p3959.html. 